\title{
DE-JURE FINANCIAL LIBERALIZATION AND ECONOMIC GROWTH: AN EMPIRICAL ANALYSIS
}

\author{
Madiha Munir \\ Ph.D. Scholar, Department of Economics (S3H), \\ National University of Science \& Technology (NUST), Islamabad, \\ madiha.munir@s3h.nust.edu.pk \\ Ather Maqsood Ahmed \\ Professor, Department of Economics (S3H), \\ National University of Science \& Technology (NUST), Islamabad, \\ ather.ahmed@s3h.nust.edu.pk

\section{Gulzar Khan} \\ Visiting Faculty, Department of Economics (S3H), \\ National University of Science \& Technology (NUST), Islamabad, \\ gulzarapk@gmail.com
}

\begin{abstract}
This paper investigated the finance-growth nexus by adopting a novel approach for Pakistan. Firstly, we constructed a financial liberalization index by incorporating several time-varying financial frictions and reforms which is a manifestation of the de-jure financial liberalization process. Secondly, for examining the impact of financial liberalization on growth, we extended the SolowSwan growth model to construct a financial sector augmented growth model. By incorporating the dejure financial liberalization index, we examined the growth-finance linkages. By employing the AutoRegressive Distributive Lag model and error-correction mechanism, the results of the study showed that de-jure financial liberalization provides momentum to economic growth in the short-run as well as in the long run. Empirical findings highlighted that moving towards a more liberalized financial system by reducing rigidities and expediting an effective reform process offers very hopeful prospects of economic growth in developing countries like Pakistan.
\end{abstract}

Keywords: Financial frictions, Financial Reforms, Economic growth, Principal Component Analysis, ARDL Model

JEL Classification: E44, F41, P34, G18, G28

\section{INTRODUCTION}

The past few decades are a witness to the financial integration of world economies owing to modifications and innovations in the financial systems of both developed and developing economies. Developed countries have adopted the financial liberalization (FL) process since 1970s while developing and emerging economies followed them in the late 1980s and 1990s. This remarkable evolution is the result of strong financial reforms process aimed at reducing financial rigidities which have been pursued rigorously by countries all over the world.

Financial frictions are key factors in driving macroeconomic fluctuations. To study financial frictions, much advancement has been seen in economic modeling. Firstly, Carlstrom and Fuerst (1997) introduced the concept of financial frictions in the form of agency cost in real business cycle models; afterwards, New-Keynesian models also incorporate financial frictions with the pioneering work of Bernanke et al., (1999). Later, the phenomenal work of Gerali et al., (2010) and Gertler and Karadi (2011) incorporate financial intermediaries in DSGE models with financial frictions by using balance sheet constraints.

Financial frictions may emerge due to endogenous and exogenous market incompleteness and/or maybe induced by government regulations. These frictions have important macroeconomic implications. They work as an accelerator mechanism for drivers of macroeconomic fluctuations enhancing the output volatility and distorting the prospects of high growth. These frictions also distort 
firm entry and their potential decisions regarding output which in turn reduces the total factor productivity and growth (Cole et al., 2016). Financial repression like interest rate controls, government borrowing, and tightening of capital movement cause disruption in the financial intermediation process and undermines the role of the financial sector for economic growth (Sriyana, 2019; Dalevska et al., 2019).

Financial reforms usually aim to reduce these frictions to enhance the efficiency of the financial intermediation process. The advocates of financial liberalization stressed that credit allocation should be market-based by adopting policies like interest rate liberalization which in turn lead to higher aggregate production and social welfare (Hsieh \& Klenow, 2009; Buera et al., 2011; Midrigan \& Xu, 2014; Moll, 2014). Many empirical studies like Quinn and Toyoda (2008) and Forbes and Warnock (2012) confirmed the positive influence of financial reforms over productivity and consumption growth. The study of Huang and Ji (2017) and a similar study by Zhang (2019) also examined the influence of financial reforms policy on the economic and financial indicators. They concluded that financial liberalization increases economic growth.

Given the importance of financial liberalization, the objective and contribution of this study are as follows. Firstly, we have constructed the financial liberalization index by focusing on financial regulations imposed by the government over time. The severity of these financial regulations has been subject to change and captured explicitly while constructing the index. This index captures the success of financial reform and also serves as de-jure financial liberalization as it is derived from policy reforms and regulations. Secondly, we have extended the Solow-Swan growth model based on Cooray (2019) to incorporate financial liberalization in the growth process directly. In this way, we have examined the impact of de-jure financial liberalization on economic growth.

The remainder of the paper is structured as follows; Section 2 is based on a review of the financial reforms process in Pakistan. The construction of the index with an econometric technique is given in Section 3. Section 4 represents the theoretical framework and empirical framework. Whereas the last part will conclude the research paper.

\section{Financial Sector Reforms}

Pakistan initiated the financial reform process in the late 1980s on the advice of the International monetary fund (IMF) and the World Bank because of financial repression in previous years. The prereform era was characterized by the prevalence of market-based distortions, negative real interest rates, provision of incentives to unproductive investments, allocation of credit to priority sectors determined by the government, and obstruction of activities of financial institutions due to excessive controls. Subsequently, economic efficiency continued to be squat and growth jiggled from comparatively truncated investment and savings rates in the private sector (Khan, 1995).

The objectives of the financial reforms are to remove the market-based distortions, competition in the banking sector, reduce government interventions and increase the efficiency and productivity in the financial sector. The first phase of the financial reform process includes the commercial banks' privatization policy, openings of new branches of commercial and foreign banks, interest rate regulations, up-gradation of money and credit markets, central bank autonomy, and prudential regulations and reforms for the development of capital markets and the external sector. Initially, the reforms process effectively transformed the financial system by gradually developing the financial markets i.e, money, capital, and exchange markets. After the privatization policy, the state ownership has declined as much that now the commercial banks can own more than half of the banking assets (SBP, 2012). Leading indicators of financial deepening and intermediation improved after the introduction of reforms i.e., M2/GDP, stock market capitalization to GDP, and credit to the private sector (Khan \& Qayuum, 2005). But these indicators are far behind the indicators of neighboring countries and the economies where the reform process had also started in the 1990s (SBP, 2019).

Presently, the financial sector of Pakistan has been upgraded with less control of the government in the transmission mechanism of monetary policy. Interest rates are moved in the specific bands introduced by the Central bank. The SBP is committed to ensuring modern regulatory and policy measures. Several regulatory and policy reforms are commenced by SBP during JulyMarch 2019. The key SBP reforms are as follows: Modern regulatory and supervisory reforms, financial stability and systematic risk assessment, national financial inclusion strategy (NFIS) and NFIS extended Action plan 2023 (Government of Pakistan, 2018-19). 


\section{Identification of Financial Frictions in Pakistan}

Financial frictions are one of the key factors that cause short-run oscillations as well as hampering the growth process. By reducing financial frictions macroeconomic volatility can be lowered and growth potential can be enhanced. The natural question asked; whether a country can reduce financial frictions through financial sector reforms? If yes, then which financial reforms are most effective? This section has answered these questions by examining financial sector reforms for Pakistan. This section is based on the construction of the de-jure financial liberalization index (FLI) for the identification of financial frictions.

\section{Construction of Financial Liberalization index}

This section measures the extent of FL in Pakistan using the most relevant variable. The index captures the exogenous changes made in policies, which ensures financial liberalization. Established on an extensive survey regarding information available on policy changes; we assess how the repressed economies move towards liberalization. Apart from a distinctive approach for the reforms process considered by Bandiera et al. (2000) and Abiad (2008), this study incorporates some other components which assumed to play an imperative role in the case of Pakistan. Based on the unique characteristics of Pakistan's economy, a different data set has been created and applied. Principal Component Analysis (PCA) has been applied to construct the index (Rencher, 2002). Overall, ten indicators have been used to construct the FLI.

1. Interest rate liberalization (IRL): In a fully-liberalized financial system, the interest rates should be market-determined. Usually, central banks directly control the interest rates or control through interest rates bands and ceilings or floor on lending and deposits rates. Based on these controls, the financial system is categorized as repressed, moderately repressed, or fully liberalized. This component captures the control measures of central banks for interest rates. More controls indicate a repressed system and vice-versa.

2. Credit Controls (CRC): Credit to priority sectors and credit at subsidized rates leads to financial repression in the economy. As, in that situation, the private sector will be deprived of credit facilities. This component will ask the following questions. Is there any minimum or maximum credit limit for the allocation of funds to priority sectors? How much credit amount is allocated to other sectors? Are the priority sectors also get subsidized credit? More directed and priority credit will only benefit the government enterprises and the private sector will be underprivileged. It lowers the value of FLI and increased financial frictions in the economy.

3. Reserve Requirements $(R V R)$ : Prudential regulations set by central banks affect the expansion credit ability of banks. A high value of reserve requirements is associated with the repression policies. Generally, $20 \%$ of reserve requirements is the threshold value.

4. State Ownership of banking assets (SOB): This component assesses the government intervention in the ownership of assets. As more percentage of assets held by the government shows financial repression. The lower the percentage of state-owned assets, the more liberalized the system will be. Increased financial activities of private banks evidenced the greater share of these banks in total assets. The degree of liberalized, moderately liberalized, and restrictive is assessed by a threshold level of $75 \%, 50 \%$, and $25 \%$ respectively.

5. Prudential regulations (PRM): This component is the opposite of all other components, as it ensures that the more government intervention, the more will be a liberalized economy. The component is related to the adoption of efficiency standards like CAMELS Framework and BASEL Accord I \& II, by commercial banks and the autonomy of the central bank.

6. Stock Market Development (STM): Stock market development plays an important role in the development of a country. The component includes the government policies which either lead to the development of the stock market or either limit its activities, for example additional privileges for foreign investors, development of equity and debt markets, etc.

7. Pro-competitive Measures (COM): Financial system characterized by healthy competition, leads to efficiency, innovation, and improves financial products. A high percentage of stateowned banks restricts the opening of private banks and limits the activities of foreign banks and non-bank financial institutions. It hindered competition in the financial sector. FL policies allowed opening new branches of commercial and foreign banks and have promoted pro-competitive measures. 
8. Share of Indirect taxes in Total taxes (SIND): Taxes are the main source of revenue for the government. Whereas direct rates play a key role as they are automatic stabilizers. However, in the case of Pakistan indirect taxes constitute a major part of total revenue. A higher level of indirect taxes as a percentage of total taxes is financial friction as it increases the burden of consumption by adding in the prices. Indirect taxes increase the cost of production and its net worth depresses. Increased indirect taxes lead the economy towards repression. This is the only study, which has used this component.

9. Excessive Public Borrowing (EPB): Excessive public borrowing interrupts the budgetary discipline due to deficit budgeting. This policy component is based on the relative share of public borrowing (\%of GDP). The repressed financial system is characterized by credit controls and credit allocations to priority sectors by the government, in such a situation, government must borrow from commercial banks to meet its excess expenditure. More public borrowing shrinks the lending capacity of the private sector. This policy component is very important in the case of developing economies like Pakistan, where federal governments mostly rely on domestic sources for short-run loans. This component is also unique for the construction of the FL index as; it also affects the liberalization process.

10. Securities Market Development (SCR): This component is comprised of government policies for the transaction of securities, developing the equity and debt markets, and liberalizing the market for foreign investors. These policies are very important for the development of security markets. The advancement and development of the security market liberalized the financial system.

Considering the above components, we adopted a scale and score approach to measuring the extent of liberalization, which ranges from 0 to 4 . The 0 indicates repressed or frictions and 4 indicates a fully liberalized or de-regulated system. However, among these numbers, 1 implies a highly repressed system, moderately repressed is indicated by 2 , and 3 represents a weakly repressed system. As each component is related to policy measures that occur at a different period and code is assigned to each component based on the implementation of policies.

To assign a score to each component, each FL reform is comprehensively examined and the score has been allocated based on the identification of policy variations. This study considers only those reforms, which have been implemented during the 1980s through 2019. So, for analysis of policy changes, various issues of SBP and GOP are studied.

The next step is the construction of the FLI based on the coding approach mentioned above. The principal component analysis (PCA) technique has been used for the construction of a single index of FLI. PCA is often utilized when there are many interrelated variables. This technique reduces these interrelated variables into a minimum number of uncorrelated variables, which are known as Principal Components. The constructed index has captured different dimensions of financial reforms and acquired the highest information from the key dataset. By employing PCA, the weightage has been calculated for each component so FLI is indicated by the following equation:

$$
\begin{aligned}
& F L I= \\
& w_{1} I R L+w_{2} C R C+w_{3} R S R+w_{4} S O B+w_{5} P R M+w_{6} S T M+w_{7} P C O M+\quad w_{8} S I N D+
\end{aligned}
$$

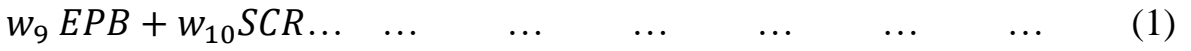

As from equation 1, FLI implies the calculated FL index for each year, $\mathrm{w}_{\mathrm{i}}$ is the weight assigned to each policy component based upon the eigenvector of the principal component.

Table 1 displays the Eigenvector and weights of policy components. In PCA, the variance of the particular component is computed; the component with the highest variation is selected. In this study, the first component $\left(\lambda_{1}\right)$ is chosen (it explains $80 \%$ variation).

Hence, calculated weights are assigned to each policy component and the final equation of FLI is described as follows:

$$
\begin{aligned}
F L I= & 0.11057 I R L+0.11079 C R C+0.0983 R S R+0.10629 S O B+0.11073 P R M+ \\
& 0.11068 S T M+0.11178 P C O M+0.10889 S I N D+0.0277 E P B+0.10452 S C R \ldots
\end{aligned}
$$


To find the value of the FLI, a respective Eigenvalue as calculated in Table 1, is multiplied by each policy component score value. A single value of FLI for each year from 1970 to 2019 has been computed by adding all ten policy components.

The final form of the FLI can be seen in Figure 1. As, from the figure, from the 1970s to 1980 was the era of financial repression. During this period, under the Nationalization Act 1974, the government takes the policy decisions, directly controlled the financial activities, and possesses all financial assets. In the early 1990s, the economy of Pakistan transforms itself under the structural adjustment program of IMF and the World Bank. The first reform process was initiated from1990 onwards in $2003^{1}$. The economy of Pakistan is still introducing reforms in the financial sector i.e., financial reforms 2019. However, several reforms are reverted i-e Privatization policy. In the preliminary process of financial reforms, 362 reforms were initiated ${ }^{2} .171$ reforms have been reported by the State bank of Pakistan ${ }^{3}$. whereas the remaining 191 reforms were stated in the Various issues of the Pakistan economic survey. In that period, the financial sector was significantly liberalized in terms of financial penetration and intermediation ${ }^{4}$. Afterward, there was a declining tendency in the FLI for Pakistan. SBP has reverted some of the financial reforms as control credit by ceilings on credit and subsidized credit. Some economic factors were also involved like freezing of Foreign Accounts, excess public borrowing by domestic sources, a heavy burden of indirect taxes, and credit to priority sectors, interest rate regulations, and monetary policy decisions. All the features are responsible for financial imperfections. Considering the above factors, it is concluded that even after modifications in the financial system still, the graph of FLI exhibits a downward trend.

These results are in line with the studies of Qureshi and Shah (2018) and, Wizarat and Hye (2010) who also constructed FLI for Pakistan and concluded that FLI reduces economic growth leading to repression. FLI reaches its highest point when the liberalization process was in the early stage. Lucas Vincent constructed financial freedom index for all economies including Pakistan using data from 1995 to 2017 (Heritage Foundation website). He also came to the point that there was more financial freedom in Pakistan from 1995 to 2000 and afterward financial freedom decreases.

Contrary to the above results, Naveed and Mahmood (2017), Fareed Ullah and Hashmi (2016), and Munir et al., (2013) reported that the financial liberalization process transforms the financial sector of Pakistan efficiently and constructed FLI was positively trended. A clear contradiction lies in the two literature strands. Firstly, these authors have used different components and sub-components to analyze FLI. Secondly, there is a difference in the coding and scaling methods of these authors.

\section{Theoretical Methodology}

This section provides the theoretical basis of the empirical relationship between the financial sector and economic growth. Many developed and developing economies modified themselves after the application of regulatory reforms. Following the work of Cooray (2009), this study has extended the Solow-Swan model to include the financial liberalization process. The model is defined as follows:

Equation 3 shows the aggregate production function with a constant return to scale. The output level is the function of physical capital, human capital, financial capital, and labor force.

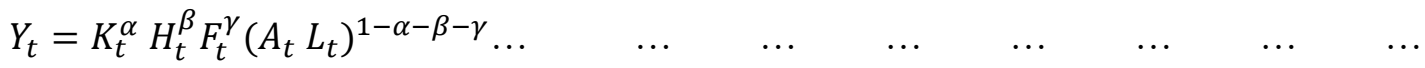

$Y_{t}$ denotes the output, $K_{t}$ implies physical capital, whereas, $H_{t}$ indicates human capital, $F_{t}$ shows financial capital, $L_{t}$ is labor and finally, the level of technology is denoted by $A_{t}$. Financial capital is used as an indicator of financial development. Output elasticities w.r.t to physical capital, human capital, and financial capital are denoted as $\alpha, \beta$, and $\gamma$ respectively. It is assumed that $L_{t}$ and $A_{t}$ grow exogenously at a rate $n$ and $g$ respectively. The depreciation rate for capita stock is indicated by $\delta$. Other symbols $s_{k}, s_{H}$, and $s_{F}$ imply the savings rate, human capital accumulation, and financial

\footnotetext{
${ }^{1}$ SBP (FSA) 1990-2000.

${ }^{2}$ Financial Sector Assessment. Annex 1 \& 2 (1990-2000)

${ }^{3}$ FSA reports 1990-2000.

${ }^{4}$ SBP report 1990.
} 
capital accumulation, respectively. So, using these variables, steady-state output per capita expressed in logarithmic form can be described as in equation 4.

$\ln \left[\frac{Y_{t}}{L_{t}}\right]=\ln A(0)+g t+\frac{\alpha}{1-\alpha-\beta-\gamma} \ln s_{k}+\frac{\beta}{1-\alpha-\beta-\gamma} \ln s_{H}+\frac{\gamma}{1-\alpha-\beta-\gamma} \ln s_{F}-\frac{\alpha+\beta+\gamma}{1-\alpha-\beta-\gamma} \ln (n+g+$

$\delta) \ldots$

... $\quad \ldots \quad \ldots \quad \ldots$

... $\quad \ldots$

After relaxing the steady-state assumption, the speed of convergence is defined as:

$\frac{d \ln y_{t}}{d t}=(1-\alpha-\beta-\gamma)(n+g+\delta) x\left[\ln \left(y^{*}\right)-\ln \left(y_{t}\right)\right] \ldots \quad \ldots \quad \ldots \quad \ldots \quad \ldots$

The steady-state output level per effective worker is defined as $y^{*}$. The output level per effective worker is implied as $y_{t} . \lambda$ is defined as the speed of convergence.

After solving eq. 5 , it follows as

$$
\lambda=(1-\alpha-\beta-\gamma)(n+g+\delta)
$$

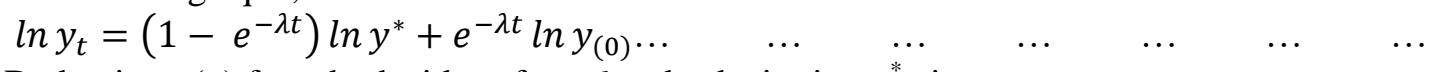

Deducting $\mathrm{y}(\mathrm{o})$ from both sides of eq. 6 and substituting $\mathrm{y}^{*}$ gives us:

$$
\begin{gathered}
\ln y_{t}-\ln y(0)=\left(1-e^{-\lambda t}\right) \frac{\alpha}{1-\alpha-\beta-\gamma} \ln s_{k}+\left(1-e^{-\lambda t}\right) \frac{\beta}{1-\alpha-\beta-\gamma} \ln s_{H}+(1- \\
\left.e^{-\lambda t}\right) \frac{\gamma}{1-\alpha-\beta-\gamma} \ln s_{F}-\left(1-e^{-\lambda t}\right) \frac{\alpha+\beta+\gamma}{1-\alpha-\beta-\gamma}(n+g+\delta)-\left(1-e^{-\lambda t}\right) \ln y_{(0)} \ldots
\end{gathered}
$$

Equation 7 can be defined in estimated form as:

$\ln y_{t}-\ln y_{(0)}=a_{o}+a_{1} \ln s_{k}+a_{2} \ln s_{H}+a_{3} \ln s_{F}+a_{4} \ln (n+g+\delta)+a_{5} \ln y_{(0)} \ldots$

We hypothesized that final result of the financial liberalization process is financial capital. Hence financial liberalization is used as an indicator of financial capital.

\section{EMPIRICAL METHODOLOGY AND RESULTS}

Built on the theoretical framework, the following model has been constructed: The study has assessed the short-run as well as the long-run correlation between Financial Liberalization and economic growth for Pakistan from 1970 to 2019. The following equation has been estimated using the ARDL and error-connection mechanism.

$Y_{t}=\alpha_{o}+\beta_{o} X_{t}+\beta_{1} F L I_{t}+\varepsilon_{t} \ldots$

$Y_{t}$ is defined as a Real GDP growth rate, however, $X_{t}$ denotes the control variables which are expenditure on education, gross investment, and employed labor force. $\alpha_{o}$ is defined as constant and FLI is the Financial Liberalization Index estimated in this study. Data sources include the FRED database and IFS data. Other sources include SBP (various issues) and Hand Book of Pakistan economy 2015 and World Bank data.

The empirical analysis has employed a time-series data series. Before estimation, it is essential to check the stationarity of the dataset. For unit-root testing, the Phillips-Perron unit root test and ADF test have been used for datasets from 1970 to 2019. Table 2 illustrates the results of both tests.

\section{Estimation of Models using ARDL}

The results of the ADF and Phillip-Peron Test indicate that all series didn't have the same level of integration; ARDL bounding testing approach can be applied to test empirical long-run and the shortrun association between FL and economic growth.

The ARDL Bound Test has been used to select optimum lag for cointegration. As lag length selection is sensitive to the results of ARDL cointegration (Bahmani-Oskooee \& Bohl, 2000). The ARDL bound test result is presented in Table 3. Pesaran et al., (2001) proposed critical values of fstatistics (for lag 1) at $95 \%$ for lower and upper bound as 2.85 and 3.91 respectively. As, from table 3 , the calculated F-statistics is 11.95 , which is higher than the critical values of the upper bound. Based on F-statistic, the analysis verifies long-term cointegration between variables.

Table 4 gives the results of ARDL models; it implies that a long-run positive significant relationship exists between FL and economic growth for Pakistan. Based on the theoretical framework, other orthodox indicators of economic growth are also incorporated. By analyzing empirical results, the FL coefficient (0.634) interprets that a one percent rise in FL leads to a $0.634 \%$ rise in GDP. Other conventional variables like expenditure on education, gross investment is also 
significant. Empirical results are in line with the studies of McKinnon (1973) and Shaw (1973) and Goldsmith (1969). They also confirmed the positive influence of FL on economic growth. They further argued that FL enhances investment and productivity. King and Levine's (1999) study also concludes that advancement in the financial sector plays an imperative role in economic development.

Table 5 defines short-run results using an error-correction mechanism. Short-run results also confirm that FL is positively related to economic growth. The error-correction term of the model has a negative sign (significant), showing that the model is converging. The estimated results revealed that any shock would not deviate the model from an equilibrium path. The functional form of the model is also appropriate as justified by the error term. The coefficient of the error-correction term is 1.461312; it specifies the extreme adjustment process. Both estimation results indicate that financial liberalization policies can strengthen the financial sector of Pakistan. The results are too reliable as financial reforms play an important role in mobilizing credit from the public sector to the private sector.

The results of diagnostic tests (Table 6) show that model used didn't suffer from any difficulty like correlation, Heteroscedasticity, and normality problems. The stability test result is reported in Figure 2 by plotting the CUSUM graph. The CUSUM graph for the estimated model lies within the limitations of critical values and confirms that all model coefficients are stable; parameters are stable and no indication of instability.

\section{SUMMARY AND POLICY RECOMMENDATIONS}

This paper provides a summary of the financial sector reforms in Pakistan. The financial sector has considerably transformed due to various structural reforms introduced since the late 1980s. It provides useful information regarding financial market imperfections in Pakistan. The focus of this paper is to recognize the extent of financial frictions in Pakistan from 1970 to 2019. To meet this objective; the study has constructed the financial Liberalization Index (FLI) for Pakistan using the principal component analysis (PCA) approach, stressing the role of government expenditures and decisions along with other significant indicators. This paper also investigates the long-run and short-run relationship between financial liberalization and economic growth for Pakistan from 1970 to 2019 by applying the ARDL model and error-correction mechanism. The results concluded that financial liberalization (FL) leads to economic growth in Pakistan.

The analysis of the financial sector of Pakistan indicates that although financial frictions have been significantly minimized, however, the financial markets are still imperfect. The value of FLI shows an increasing trend from 1990 till 2001. In that period, the FLI indicates that the liberalization process in Pakistan was successful in its early phase, but gradually it starts diminishing after 2001 slowing down the reform process. The index reflects that the reforms process advances the financial sector by moving from suppressed to a market-based financial system combined with the advancement of capital, credit, and the stock market. Though the index shows downtrends, still financial reforms improve the banking sector and stock markets in the said period compared with the pre-reform era. But these developments only show in the initial years of the reform process.

In short, in the wake of the financial liberalization process, Pakistan has made progress in some sectors and introduced various policies. Yet Pakistan's policy of financial liberalization (FL) reveals a downward trend since 2001. For the development of the money market and to reduce nonperforming loans, there is a need to introduce further reforms compatible with other developing countries that have shown remarkable improvements in their financial sectors. It is also seen that even after privatization in the banking sector; still, government-owned banks hold the largest share with weak profitability. So, there is a need to focus on the privatization policy so that healthy competition could be seen in the banking sector. It is also proposed that forthcoming policies on financial liberalization would be introduced with great integrity and will deliver an atmosphere conducive to achieving desired economic goals.

\section{REFERENCES}

Abiad, A., Detragiache, E., \& Tressel, T. (2008). A new database of financial reforms. IMF Staff Papers, 57, 281-302.

Adrian, T., \& Jones, B. (2018). Shadow banking and market-based finance. International Monetary Fund. 
Adrian, T, \& Shin, H. S. (2010). The changing nature of financial intermediation and the financial crisis of 2007and 2009. Annual Review of Economics, 2(1), 603-618.

Bahmani-Oskooee, M., \& Bohl, M.T. (2000). German monetary unification and the stability of the German M3 money demand function. Economics Letters, 66(2), 203-208.

Bandiera, O., Caprio, G., Honohan, P., \& Schiantarelli, F. (2000). Does financial reform raise or reduce saving? Review of Economics and Statistics, 82(2), 239-263.

Beck, T., \& Levine, R. (2004). Stock markets, banks, and growth: Panel evidence .Journal of Banking \& Finance, 28(3), 423-442.

Bernanke, B. S., Gertler, M. \& Gilchrist, S. (1999). The Financial Accelerator in a Quantitative Business Cycle Framework. Handbook of Macroeconomics, ed. by J. B. Taylor, and M. Woodford. Elsevier.

Blanchard, O. (2017). On the Need for (At Least) Five Classes of Macro Models. Peterson Institute for International Economics, Washington, DC.

Buera, F. J., Kaboski, J. P., \& Shin, Y. (2011). Finance and Development: A Tale of Two Sectors. American Economic Review, 101, 1964-2002.

Carlstrom, C. T., \& Fuerst, T. S. (1997). Agency Costs, Net Worth, and Business Fluctuations: A Computable General Equilibrium Analysis. American Economic Review, 87(5), 893-910.

Cole, H. L., Greenwood, J., \& Sanchez, J. M. (2016). Why Doesn't Technology Flow from Rich to Poor Countries? Econometrica, 84, 1477-1521.

Cooray, A. (2009). The Financial Sector and Economic Growth. The Economic Record, The Economic Society of Australia, 85(1), 10-21.

Creane. S., Rishi, G., Mobarak, A. M., \& Randa, S. (2004). Financial Sector Development in the Middle East and North Africa. IMF Working Paper 04/201.

Dalevska, N., Khobta, V., Kwilinski, A., \& Kravchenko, S. (2019). A model for estimating social and economic indicators of sustainable development. Entrepreneurship and Sustainability Issues 6(4): 1839-1860.

Fareed Ullah, S., \& Hashmi. S. M. (2016). Financial development and economic growth: a panel cross-country study. Jinnah Business Review, 4(1), 9-21.

Forbes, K. J., \& Warnock, F. E. (2012). Capital flow waves: Surges, stops, flight, and retrenchment. Journal of International Economics, 88(2), 235-251.

Gerali, A., Neri, S., Sessa, L., \& Signoretti, F. M. (2010). Credit and Banking in a DSGE Model of the Euro Area. Journal of Money, Credit, and Banking, 42 (1), 107-141.

Gertler, M., \& Karadi, P. (2011). A model of unconventional monetary policy. Journal of Monetary Economics, 58(1), 17-34.

Goldsmith, R. (1969). Financial structure and development. New Haven: Yale University Press.

GOP. Various Issues. Pakistan Economic Survey. Ministry of Finance, Government of Pakistan.

Heritage Foundation and Wall Street Journal (Firm). (1995). The index of economic freedom. Heritage Foundation Washington, DC.

Hsieh, C.T., \& Klenow, P. J. (2009). Misallocation and Manufacturing TFP in China and India. The Quarterly Journal of Economics, 124, 1403-1448.

Huang, Y., \& Ji, Y. (2017). How will financial liberalization change the Chinese economy? Lessons from middle-income countries. Journal of Asian Economics, 50, 27-45.

Hyder, Z. (2015). Optimal Monetary Policy with Capital Formation and Financial Frictions. Unpublished Manuscript. Centre for Applied Macroeconomic Analysis (CAMA) The Australian National University.

Khan, A. H. (1995). Need and Scope for Further Reforms in the Financial Sector in Pakistan. Journal Bankers Institute of Pakistan, 61, 41-58.

Khan, M. A., \& Khan, S. (2007). Financial sector restructuring in Pakistan. Lahore Journal of Economics, 12(Special Edition), 97-125.

Khan, M. A, Qayyum, A. \& Sheikh, S. A. (2005). Financial Development and Economic Growth: The Case of Pakistan. Pakistan Development Review, 44(4): 819-837.

King, R. G., \& Levine, R. (1993). Finance and growth: Schumpeter might be right .Quarterly Journal of Economics, 108(3), 717-737.

Koch, C. (2015). Deposit interest rate ceilings as credit supply shifters: Bank-level evidence on the effects of regulation. Quarterly Journal of Banking \& Finance, 61, 316-326. 
Levine, R. (1997). The legal environment, banks, and long-run economic growth. Journal of Money, Credit and Banking, 30(3), 596-613.

Levine, R. (2001). International Financial liberalization and economic growth. Review of International Economics, 9(4), 688-702.

McKinnon, R. I. (1973). Money and capital in economic development. Washington, DC :Brookings Institution.

Mertens, K. (2008). Deposit rate ceilings and monetary transmission in the US. Journal of Monetary Economics, 55, 1290-1302.

Midrigan, V., \& Xu, Y. D. (2010). Finance and misallocation evidence from plant-level data. NBER Working Paper Series No. 15647.

Moll, B. (2014). Productivity Losses from Financial Frictions: Can Self-Financing Undo Capital Misallocation? American Economic Review, 104, 3186-3221.

Munir, S., Chaudhry, I. S., \& Akhtar, M. H. (2013). Financial Liberalization and economic growth in Pakistan: Empirical evidence from the co-integration analysis. Pakistan Journal of Social Sciences, 33(2), 227-241.

Naveed, S., \& Mahmood, Z. (2017). Impact of domestic financial liberalization on economic growth in Pakistan. Journal of Economic Policy Reform, 1-19.

Ozcan, K. M., Gunay, A., \& Ertac, S. (2003). Determinants of private savings behavior in Turkey. Applied Economics, 35(12), 1405-1416.

Pesaran, M.H., Shin, Y., \& Smith, R. J. (2001). Bounds testing approaches to the analysis of level relationships. Journal of Applied Economics, 16, 289-326.

Pozsar, Z., Adrian, T., Adam, A., \& Hayley, B. (2013). Shadow banking. FRBNY Economic Policy Review.

Quinn, D. P., \& Toyoda, A. M. (2008). Does capital account liberalization lead to growth? The Review of Financial Studies, 21(3), 1403-1449.

Qureshi, S. A, \& Shah, S. M. A. (2018). Financial liberalization index for Pakistan: A factorial Approach. Abasyn Journal of Social sciences, 11(1), 49-60.

Rencher, A. C. (2002). Methods of Multivariate Analysis. 2nd ed. New York: John Wiley.

SBP. Various Issues (a). Annual Reports. Karachi: State Bank of Pakistan.

Shaw, E. S. (1973). Financial deepening in economic development. New York: Oxford University Press.

Sriyana, J. (2019). What drives economic growth sustainability? Evidence from Indonesia. Entrepreneurship and Sustainability Issues, 7(2), 906-918.

Stiglitz, J. E., \& Weiss, A. (1981). Credit rationing in markets with imperfect information. American Economic Review, 71(3), 393-410.

Tufail, S., \& Ahmed, M. A. (2018). Financial frictions and optimal policy response. PIDE Conference Proceedings. $34^{\text {th }}$ AGM, PSDE, PIDE.

Tufail, S., \& Ahmed, M. A. (2019). Finance-Growth Nexus and relative efficacy of alternative policy regimes: An investigation for Pakistan. Forman Journal of Economic Studies, (15), 23-67.

Wang, N., Shah, H., Ali, M., Abbas, K., \& Ullah, S. (2019). Financial Structure, Misery Index, and Economic Growth: Time Series Empirics from Pakistan. Journal of Risk Financial Management, (12), 80-100.

Wizarat, S., \& Hye, Q. (2010). Financial reforms and industrial sector growth: bound testing analysis for Pakistan. South East European Journal of Economics and Business, 5(2), 75-81.

Zhang, S. (2019). The effect of financial liberalization on economic growth: A panel data analysis of 38 countries. Lund University Press (LUP) student papers. 
APPENDIX

Table No. 1 Eigenvectors and Weights for Policy components

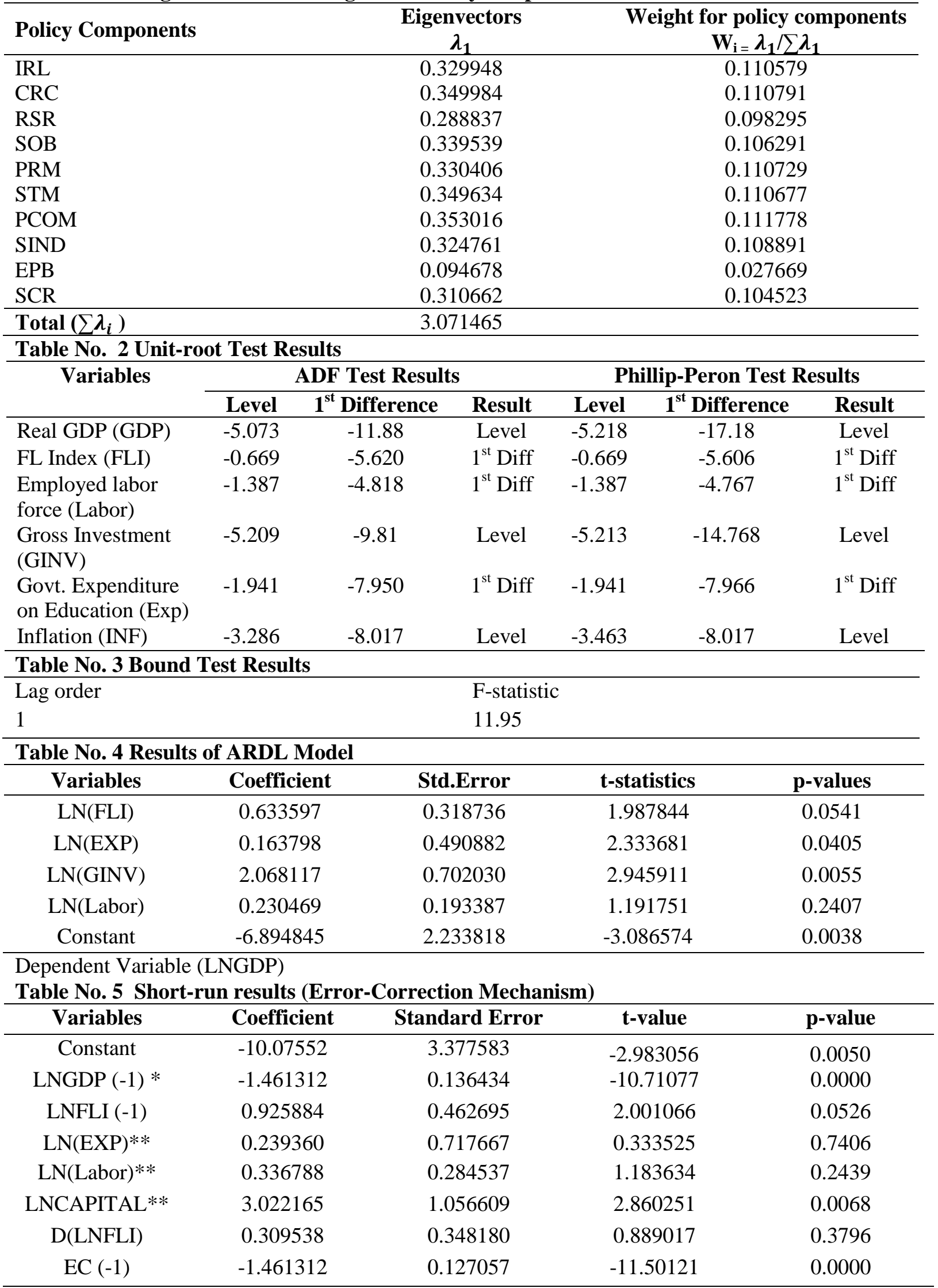

Note: Dependent Variable LNGDP

*Implies significance at $1 \%$ level. 
**Implies significance at $5 \%$ level.

*** Implies significance at $10 \%$ level.

Table No. 6 Results of Diagnostics Test

Serial Correlation LM Tests

Obs* $\mathrm{R}^{2}$

2.897814 (0.0834)

Heteroscedasticity Test (Bruesh-pagan-Godfrey)

Obs* $\mathrm{R}^{2}$

$18.7026(0.000)$

Normality Test

Jarque-Bera

$124.0420(0.000)$

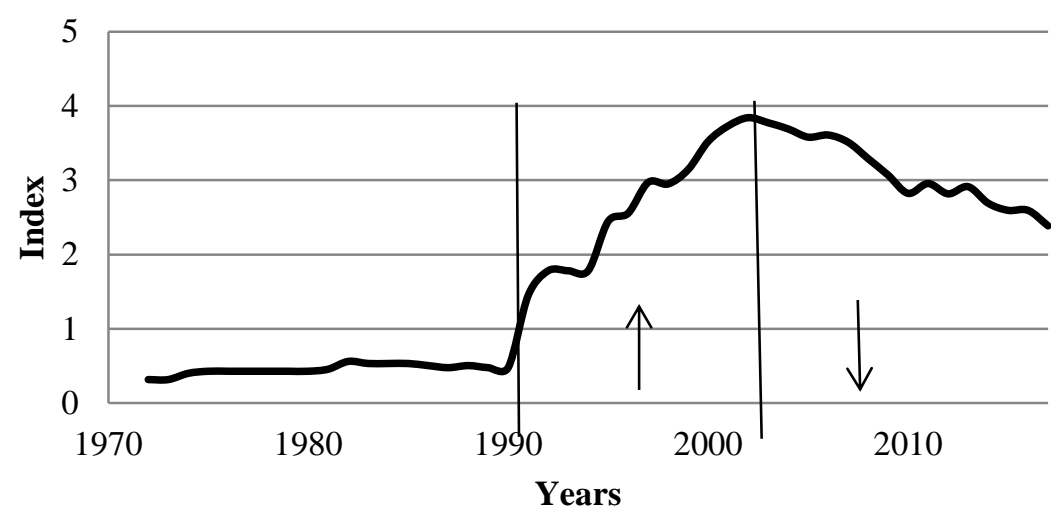

Figure 1 Financial Liberalization Index (FLI) (Estimated)

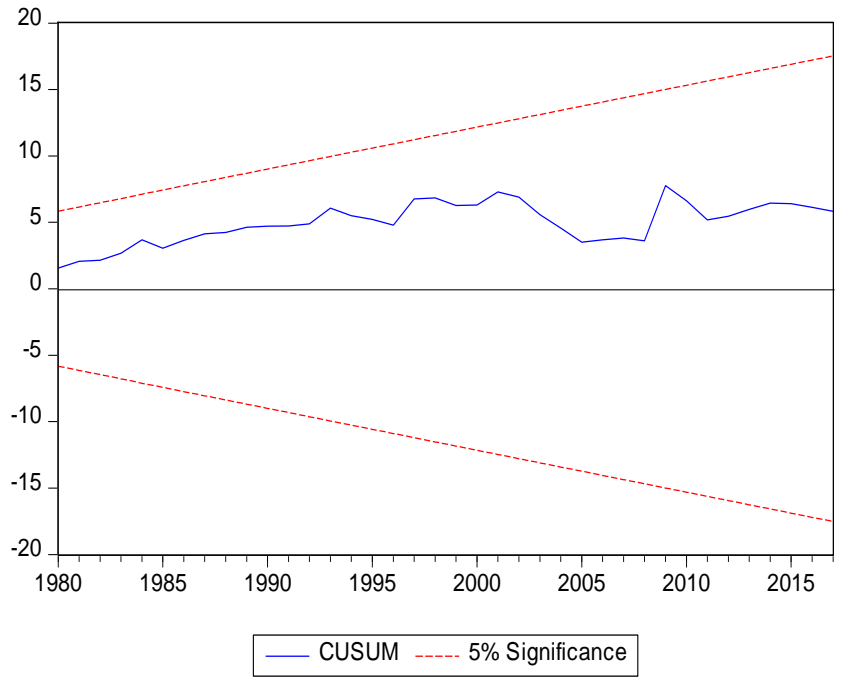

Figure 2 Results of Stability Test 